\title{
from Tryst
}

\author{
nathalie stephens
}

$S i$, dans ces textes, où la mémoire fait figure d'enfant terrible, l'enfant y est, en apparence, soustraite, elle y laisse néanmoins la térébrante trace de sa présence. Elle tente d'esquiver le texte, qui n'a de cesse de la rattraper. Le corps est le lieu premier de nos territoires contestés.

\section{Title}

The man sits at the head of a table. His father is dead, and he is glad of this.

He rocks back and forth rubbing the skin between his index and thumb bare. He mutters like his father before him, the prayers of a grown man. He dips bread in salt. He gulps wine and swills it around his mouth before swallowing.

Although he is young yet, he smells of sex and sweat, like his father before him. He doesn't light candles.

His wife takes food from his lips. They create this ritual.

"I will fill you up," he says when he meets her.

She nods.

"Fat fingers for such a skinny man."

Love. There it is, in the mouth of a man. They bury his father and are married. They eat figs and a pièce montée. Three times, her head is dipped in water.

"So this is what it feels like to drown," she says.

The man eats with his fingers. He is an art dealer. Ask him anything, he will tell you what it's worth.

He keeps a girl in a shoebox. At night he lets her out, while his wife sleeps. The girl has only one hand, which she uses to cover her eyes. 


\section{Title (II)}

Twice, a story told, by two people.

Once, in the mouth of the mother. Once, in the mouth of the son.

The daughter is in a dark room, all alone. There is a knife and a table. And there is the moon through a crevice in the wall.

She bites a hole into her arm and the wind passes through it, like light, or disease. That translucent. That irrevocable.

Somewhere just out of reach is a word carved into a concrete block. It is illegible, but she runs her fingers across it nonetheless. Without paper for her thoughts, she takes to writing out loud, the same words, over and over again.

There is memory. And time elapsed. And the certainty that a thing past is an unalterable thing.

Whether or not to speak it.

The son is a fisherman. This is what he says. With bait and nets and fishing rods, perched upon a rock overlooking a great body of water.

"What is mine."

He is not speaking to a particular person. Rather with the certainty that someone will turn to him, and listen.

"Mine."

The story is in fragments. Held securely between teeth. In the mouth of the mother. In the mouth of the son.

The girl chews on her knees. She is making art with bruises. She tries to make art with song, but the echo comes and deafens her. Now she uses her teeth, not her tongue.

A stone pier jutting across water. And a row of gutted fish.

"What is mine."

How the story is told, and to whom.

Somewhere, teeth chipping bone. Manacles of light. 


\section{from Tryst $\cdot 103$}

\section{Reel}

You are breathing fire into the sandbox. Your mother is hanging from the bathroom window, clutching fistfuls of hair.

Someone pisses the bed again. There is graffiti on the living room floor, a trap door, tunnels driven into hard rock.

Chalk on the sidewalk. Tar in your hair. Your mouth full of cotton wool (too many teeth).

You board a night train, sleep on the floor with your eyes wide open. (Tracks).

In the morning, you sip mist from the air. Sit all day at the foot of a lemon tree, wait for Apollinaire.

(You do not bring a gun along. The hole in his head is already big. Instead you offer him wine, then chop off his feet).

Paris is a conspiracy. You run through the streets, knocking down buildings, tipping your hat to all the pretty boys. Dirt under your nails, scuffed knees. 